\title{
Managing urban unrest: problematising juvenile delinquency in multi-ethnic Sweden
}

Magnus Dahlstedt and Vanja Lozic

The self-archived postprint version of this journal article is available at Linköping University Institutional Repository (DiVA):

http://urn.kb.se/resolve?urn=urn:nbn:se:liu:diva-163988

N.B.: When citing this work, cite the original publication.

Dahlstedt, M., Lozic, V., (2017), Managing urban unrest: problematising juvenile delinquency in multiethnic Sweden, Critical and radical social work An international journal, 5(2), 207-222.

https://doi.org/10.1332/204986017X14933953111175

Original publication available at:

https://doi.org/10.1332/204986017X14933953111175

Copyright: Policy Press

http://www.policypress.co.uk/ 


\title{
Managing urban unrest: problematizing juvenile delinquency in multi-ethnic Sweden
}

\author{
Magnus Dahlstedt \& Vanja Lozic
}

\section{Introduction}

Since the new Millennia, the rise of 'urban social movements' and 'urban uprising' in European cities, has sparked a heated debate on the problem of 'urban youth' and 'urban unrest' throughout Europe (Mayer, et al. 2016). Correspondingly, in the Swedish urban context, areas built as a part of the large-scale housing project in the period between 1965 and 1975, the so-called 'Million Programme', have become sites of social conflicts, expressed in violent uprisings, setting cars and schools on fire or in local confrontations between youth and the police (Hallin, et al. 2010; Abiala, 2014; de los Reyes, et al. 2014; Magnusson, 2014; Schierup, et al. 2014; Dahlstedt, 2015). More recently, these areas have come to been classified as 'vulnerable areas'. In Sweden, there are 53 geographical areas (distributed among 22 cities) classified as vulnerable, out of which fifteen areas are classified as particularly vulnerable. This study has been conducted in one of these areas.

Building on the images of social problems in the areas as well as recent conflicts between youth and authorities, the aim of this article is to analyse representations of causes of and solutions to the problem of juvenile delinquency in one particular urban area, in the article referred to the Neighbourhood. The analysis is based on interviews with the representatives for civil sector, state and municipality as well as on participant observation from network and partnership meetings between these representatives. The analytical point of departure in the article is the concepts of problematisation (Foucault, 2004; Bacchi, 2010), highlighting the rationalities of governing through which "rule is rationalized and rendered "effective",; that is to say the professes of identification, mapping and understanding of a 'problem', explaining it, and visualising, justifying and implementing 'problem-solutions' (Bacchi, 2012: 5).

A wide range of subject matters permeates the empirical material; nevertheless, the analysis reveals that some themes prevail more than others. Briefly, the analysis indicates that the representations of causes of problems consist of a wide range of explanations (i.e. the urban environment characterised by unemployment, poor housing and schools and presence of criminality, issues of migration and the culturalisation of social problems etc.) but also that there is a prominence of specific solutions (i.e. the normalisation and activation of residents in general and parents in particular). In the concluding section of the article, this discrepancy between problem representations and proposed solutions is further discussed, particularly in the light of on-going changes of welfare policy, with a shift of responsibility from the state to individual citizens.

\section{Analytical framework}

The analytic framework is based on the premise that governing is made possible by problem representations, implying that governing takes place through the activity of mapping out and representing a 'problem' and particular regulatory practices initiated in order to deal with this 'problem' (in this article the problem of juvenile delinquency). Governing may thus be understood as problematizing activities, whereby certain phenomena, domains or subjects in society are represented as 'problematic' and thus in need of intervention (Miller and Rose, 2008). Hence, through problematizing activities, certain phenomena, domains or subjects are 
made governable, i.e. the target of governing practices, operating throughout society. Drawing on Bacchi $(2009,2010)$, we focus on the role of policy makers and practitioners in resolving the 'problems' they give shape to. This notion of problem representation and problem-solution can be understood as modelling the space of government (Rose, 1999), meaning that we are not focusing on why a particular 'problem' exists, but rather on how this particular 'problem' is conceptualised - i.e. problematised.

Thus, problematisation is used as an analytic tool giving 'important insight into the thought (the "thinking") that informs governing practices' (Bacchi, 2009: xiii). By 'focusing on the knowledges through which rule takes place, and the influence of experts and professionals on and through these knowledges' (Bacchi, 2009: 26), we further investigate: i) how something is put forward as a cause of a certain problem (problematized), i.e. the problem of juvenile delinquency, what the rationalities of the problem representations are, ii) which premises are taken for granted and which are silenced and un-problematized, iii) how this kind of problemrepresentation has come about and how it has been defended, and iv) what the effects of a particular understanding of the 'problem' might be. In terms of possible effects, we may distinguish three interconnected forms of effects: discursive effects (what is presented as truth and on which arguments these truths are based), subjectification effects (which subject positions, such as professionals and citizens, are made possible) and lived effects (the impact of solutions on people's everyday lives and relations in the analysed areas and society at large). Relating to Swärd (1993: 245) and Ekberg (2010), we use the term juvenile delinquency as an umbrella term for the behaviours of young people in conflict with the norms and laws of society. Due to the problematisation of these behaviours, authorities are then compelled to react and initiate certain measures.

The empirical material analysed consists of interviews with twenty representatives of municipal, state and non-governmental organizations, working for and with young people in the Neighbourhood, as well as field observations and field notes. By contacting key individuals responsible for partnership initiatives for the development of the Neighbourhood we gained access to the field. Whereas, fieldwork was conducted between 2014 and 2016, during network meetings and other activities organised within various partnership initiatives, interviews with twenty representatives for the police, emergency service, schools, social service, civil sector and municipality were conducted during 2014. In all, the interview material consists of over thirty hours of interviews with three police officers, seven representatives from the voluntary sector and youth NGOs, two area developers, two school principals, four professionals engaged in dealing with psycho-social issues and two dealing with safety and security issues. The drama teachers, social workers, school principals, police officers, risk and safety workers, psychologists, youth coaches and youth leaders, project managers and field coordinators were interviewed because of their experiences of working with youth and for their participation in partnership initiatives targeting youth in the Neighbourhood. All pieces of information that could disclose the identity of specific individuals and places have been anonymised.

In the analysis, the empirical material has been interpreted within the framework of the analytical perspective on problem-solution described. This means that we have interpreted the empirical material as problematisations and constructions of solutions in relation to juvenile delinquency. Even though the empirical material covers a variety of themes, the main focus of the analysis is on the understanding of the causes of juvenile delinquency in the area and the solutions advocated. Drawing on a discourse analysis influenced by the work of Foucault (1991), discourses are seen not as simply reflections of 'reality', but rather as structuring what 
is thinkable and articulated about certain issues, defining problems as well as proper solutions to these. Thus, in the process of interpretation, the statements analysed were divided into the topics of problematisations and solutions. In the empirical material, there was a variety of representations of problems and solutions. Focusing on the way in which these problems and solutions are interwoven, we were able to further analyse the basic notions and understandings of juvenile delinquency structuring the discourses about the Neighbourhood, the families living there, and about solutions for social change. In the following analysis, we will then focus on the prevailing representations of problems and the solutions made possible. The main body of empirical material analysed in the article consist of interviews. However, in the last section of the analysis, focusing on solutions, interviews are complemented with field observations and field notes, in order to give a more detailed account of the ways in which representations of problems give rise to specific solutions targeting those defined as problematic.

Now, having presented the analytical and empirical points of departure, we will now turn to the broader political context of the study.

\section{'Areas of exclusion' contextualized}

Considering images of disorder and threat in current discourses on 'particularly vulnerable areas' or 'areas of exclusions', it is crucial to note that such images are not new. As a matter of fact, the discursive constructions of the 'Million Programme' in terms of Otherness and socalled 'parallel societies' has a long history (cf. Ristilammi, 1993; Molina, 1997; Brune, 2004; Sernhede, 2002, 2011; Kamali, 2014). For instance, Pearson (1983) and Swärd (1993) have analysed similar discourses of the rise of violence and disorder, threatening the fabric of society and the moral deterioration of British and Swedish working class youth during the early $20^{\text {th }}$ Century. Current arguments focusing on the relation between youth 'deviancy' and 'dysfunctional' family relations in the areas of the 'Million Programme' - and elsewhere emphasizing the need for society to intervene in order to enhance social cohesion and to 'normalise' the families, have in fact permeated social policy in modern nation states (Swärd, 1993, Kamali, 2002, Jönsson, 2013). Here, the main argument has been that some parents, those with migrant background, but previously also those from the working class, lack the knowledge, ability and responsibility to socialise children in accordance with 'desirable' norms. Among others, Jönsson (2013: 165) emphasizes that such 'culturalisation of social problems' tends to divert attention from wider societal and structural settings, such as segregation, discrimination or deprived housing, and instead focus on the 'deviant' others as the bearers of the problems (cf. Kamali, 2002; de los Reyes and Kamali, 2005; Stigendal, 1999).

Similarly, current problem discourses about the 'areas of exclusions' can be placed in a longer history of the Swedish urban areas commonly associated with 'The Million Programme', which was a comprehensive state-directed housing construction programme characterized by a quick construction process and standardisation; with the aim of constructing one million dwellings between 1965 and 1975. In the 1970s, the problem discourses concerning these areas revolved around the residents' working class background and low educational attainment. Since the 1980s, issues of migration, cultural differences and ethnic segregation have been dominant frames of reference in the representation of these areas (Ristilammi, 1993; Kamali, 2006; Nordström Skans, et al. 2010; Dahlstedt, 2015). In addition to these representations, since the new millennium, images of violent (migrant) suburban youth serve as central interpretative framework for the representation of the areas in general and the challenges policy makers and professionals encounter while intervening in order to deal with these areas and its residents (Mulinari, L.S, 2015). However, while the ways in which 'The 
Million Programme' has been problematized have varied over time, the discourse on these areas have for long been permeated by an underlying fear of disintegration of society and a threat to social order and cohesion.

As with the representation of problems and the causes of problems, the representations of problem-solutions have varied in the past few decades. Between the 1950s and the 1970s, the Swedish welfare state enjoyed international reputation for being able to combine economic growth and industrial expansion, with full employment, comparatively equitable income distribution and general social insurance scheme (Dahlstedt, 2009b; Svensson, 2010). In this context, a strong public sector, universalism, solidarity, consensus, a sense of common good and responsibility for all, and democracy were featured as progressive, modern and legitimizing rudiments of Swedish welfare state (Rothstein, 1998). The extent to which these virtues were incorporated in the common narrative about welfare state can be illustrated by that socio-political dogma that crime, for instance, was not 'a unique [personal] problem, but [...] an effect of the social situation' (Svensson, 2010: 50). Thus, social work played a key role in criminal justice, signifying the prerequisite of establishing personal relations, developing (multi)cultural competences; exertion of empathy, caring and concern, for not only victims but also offenders (Jönsson, 2013; Kamali, 2002). Under these circumstances, it is not surprising that Sweden was named a 'caring-state', offering 'citizens not only social security against the pitfalls of the market but also promise of high-quality care for the very dependent' (Leira, 1994: 185). Following the same logic, the early history of 'The Million Programme' was permeated by predominantly top-down governance and transformative interventions, projects and programmes, which symbolized a collective will and sense of political responsibility, typical of the political rationality of the social-democratic welfare state (Ålund and Schierp, 1991).

However, due to the economic problems in the late 1980s and early 1990s, and an increasing influence of neoliberal governmental rationalities, the welfare state came under attack and its most fundamental elements were challenged (Boréus, 1994; Larsson, et al. 2012). The key argument in the representation of the problems of governing was now that the Swedish state apparatus was pervaded by (too) centralised solutions, inefficient state control and paternalistic treatment of citizens, and that such governing was not well equipped to cope with the challenges of an increasingly globalised world, where it is seen as necessary to take the freedom of the individual into account and let her take responsibility (Chandler, 2014; Korpi, et al. 2003).

Consequently, the contours of a new Swedish model emphasizing the obligations of active citizens over their rights have emerged (Junestav, 2004; Schierup, et al. 2015). Accordingly, Sweden has witnessed a downsizing of responsibility of the state for welfare policies and a decentralisation of governing, an increased emphasis of a bottom-up approach and reallocation of responsibility from state to voluntary sector and individual citizens. This set of strategies have in various ways generated an activation and responsibilisation of citizens and a proliferation of community-led partnerships between various stakeholders, ranging from public and private to civil society actors, as well as individual citizens (Dahlstedt, 2009b; Jönsson, 2015). The importance of such partnerships, including not least partners such as the police, social work and school, has in the last decades been particularly emphasised when it comes to meeting challenges following in the wake of an increase in social exclusion and urban polarization (cf. Hertting, 2003; Kings, 2011; Bengtsson and Hertting, 2015). 
This is this political context in which the study is set. Now, let us turn to the empirical material and the ways in which the problem juvenile delinquency in the Neighbourhood is constructed, in terms of the causes addressed and the solutions advocated in order to meet this particular problem.

\section{Dominant problematisations}

The analysis begins with the representations of problems, followed by the solutions emphasized. When it comes to representations of problems, there are two main and interrelated problematisations: the locality as a problem and the migrant background of the parents as a problem.

\section{Problematizing the locality}

The main framework for problematisations of the youth in the Neighbourhood in general and juvenile delinquency in the area in particular is the urban environment of the Neighbourhood, represented as having completely different conditions, rules and norms than those in the rest of the City and Swedish society at large. Being comprehended in this manner, the Neighbourhood is understood as a breeding ground for criminality and other forms of subversive behaviours amongst the youth, leading the interviewed to engage in different interventions, with the aim to facilitate positive changes.

The interviewees emphasise that not only housing infrastructure and school buildings are deprived, neglected and in many cases 'catastrophic' in the Neighbourhood, but also that school results and behaviour in schools pose real challenges for all organisations operating in the the Neighbourhood, including the police and emergency service. Consequently, it is said that both school personnel and the police have been forced to intervene at regular basis in order to handle fights and gang conflicts. In the words of principle Henrik, his school would have been closed with immediate effect if it was located in another part of the city. Similarly, the police officer Andreas contrasts the situation in the Neighbourhood with the living conditions in other areas of the city, "where school activities function well, where you have motivated friends who are interested in sports and education'. Hence, in these and other problematisations the Neighbourhood serves as a counter image to more 'normal functioning' areas of the city.

By the same token, resembling the images of deprived working class neighbourhoods during the early $20^{\text {th }}$ century (Swärd, 1993; Pearson, 1983), the unemployment amongst the residents of the Neighbourhood is put forward as a major concern, leading to a situation where the culture of unemployment is passed on from one generation to another, or as the social worker Olivia puts is, unemployed parents 'become role models for the children, and unemployment becomes the norm'. Following this line of argument, she asserts that when asked 'What will you be when you grow up?, young people answer 'Well, I do not know, I'll be nothing'. In relation to such dystopian images of the future and the deprived current circumstances, the police officers interviewed, Andreas, Ingvar and Jesper, all argue that some young people seek opportunities in crime, as it offers a way out of poverty, provides them with security and a sense of belonging, and gives them a reputation - of being someone.

Another prevailing argument, which in fact permeates all other causal explanations for youth problems and juvenile delinquency, is that the Neighbourhood has an excessive concentration of migrant residents, who amongst other things have a propensity for establishing strong ethno-cultural communities, thus forming some kind of parallel societies. For instance, Maria, who works as a youth coach for an NGO, designates that many residents of the Neighbourhood are 'being alienated from the rest of society' and confine themselves to 'small 
communities', where 'they live in their own reality'. Based on her intimate and often intensive work and long experience of working with youth in the Neighbourhood, Maria draws the conclusion that many parents 'have not learned the language', are involved in ethno-cultural communities and obtain information from foreign satellite and TV channels. The point being made is the following: Over time, the concentration of migrants to specific areas, together with the development of ethno-based communities, along with a lack of Swedish identity amongst the young (who were born and raised in Sweden, but who primarily identify themselves in relation to their parents' country of birth, the Neighbourhood and their migrant background), all lead to an increasing distrust of society, its institutions and representatives among the youth. This, in turn, makes the youth turn to drugs and criminality.

Referring to Molina (2005), it is obvious that Sweden in comparison to other OECDcountries, has for decades had a highly racialized housing segregation, as a consequence of processes of discrimination. However, in the dominant discourses about the causes of this segregation, there has been a neglect of the long history of discrimination. Instead, the main focus has been either on the neoliberal discourse of 'freedom of choice' or on discourses culturalising migrants and their behaviour (de los Reyes and Kamali, 2005). In both discourses, it is the migrants who appear as responsible for this development, and in this context the role of the parents is crucial. In the following, we will thus focus on the representation of family relations and parents as an important framework for the understanding of youth problems in general and juvenile delinquency in particular.

\section{Problematizing migrant parents}

The principal Henrik's experience from managing a compulsory school in the Neighbourhood is that 'parents care very little about the school', despite the fact that both the school building and the learning environments as such have for a long time been quite neglected and deprived. Similarly, the principal Carina argues that:

\footnotetext{
We rarely succeed in getting many parents at parent-teacher conferences. The biggest turnout is amongst the parents who have a job and are part of society; and it's not all parents who have managed this. [...] Among the more economically powerful groups, [in the areas] where there are more highly educated parents, there the schools come into question. It is not the best thing for the school to be challenged by the parents, but the parents in [Neighbourhood] are passive.
}

Henrik and Carina both argue that there is a problem with the parents in the Neighbourhood, compared to parents in other parts of the city. However, the ethno-cultural background of the parents is not emphasized, as such. The same line of argument is put forward by youth coach Maria, concluding that many parents in the Neighbourhood 'do not encourage their children, not in any way'. In her mind, this is because 'they do not have the ability to encourage children and give them positive attention that strengthens them'. Based on such characterization, she claims that 'parents do not know in all situations how to encourage children'. In such problematisations, parents living in the Neighbourhood, are represented as different to the residents and parents of the more affluent areas in the city, where parental involvement in children's schooling and society at large is regarded as much greater.

Referring to Kamali (2009: 261), there is a predominant stereotype in many European countries, according to which 'immigrant parents are less enthusiastic, less involved and less concerned with the outcome of their children's education'. Such culturalised representations of the 'migrant parent', problematizing parents' lack of involvement in relation to the parents' migrant background has been found also in other previous studies. Indicative of such representations is the notion that migrant background per se is a risk factor that may lead to 
the destabilisation of family and social relations (cf. Ålund, 1991; Mattsson, 2005; Grillo, 2008; Kamali 2009; Eliassi, 2014). A similar rationality is present also in the interviews conducted, and particularly among some of the interviewees. In line with such reasoning, for instance, emergency service worker Patrik argues that migrant parents have 'seen terrible things, which they have not been able to deal with, so they cannot move on with their lives'. They are, so to speak, stuck in history, unable to deal with the challenges in life of today. Similarly, Thalia, a manager for an NGO working with young people, argues that 'many [parents] have come from difficult circumstances and can't bother to get involved'.

Furthermore, the problematisation of the parents with migrant background is frequently related to the parents' insufficient knowledge of Swedish and their lack of integration in Swedish society, i.e. a lack of understanding of cultural and other norms in society. The youth coach Maria speaks of many 'parents, who can not find their bearing in society' and who thus 'lead a life of their own, which is quite different from the norm'. She believes that this greatly hampers future prospects of children and adolescents. Principle Carina, who also links language deficiency amongst parents and children's future prospect, argues that if about half of parents don't understand what you're saying then there is no purpose in parent-teacher conferences'. Correspondingly, the police officer Ingvar puts an emphasis on language as a barrier, but here in relation to inverse family and generational roles.

I have employees who hold inquiries at home, in an apartment, talk to parents who don't speak Swedish. Children speak better Swedish, so the kids deceive the parents by lying or not telling the whole truth to their parents, because they don't speak the language.

According to Ingvar, the consequence of parents' language deficiency is an inversion of parent-child relationships. Not only do children act as interpreters, but parents also become dependent on their children as well as isolated in their homes, finding it increasingly difficult to set limits in relationship with their children. Similarly, Nicklas, who works as a municipality manager, argues that at home 'the son dominates very much, starts to call the shots and pull the strings', and turs to 'criminality and drugs'.

However, it is important to underline that problematisations of family relations and parents' knowledge deficiency, is more about them having wrong and/or inappropriate knowledge rather then not having knowledge at all. A recurring problem representation is that some migrant parents have an experience of living in political systems and cultures very different from the 'Swedish'. It is argued, that this, in turn, causes a number of serious problems (cf. Gruber, 2007; Dahlstedt, 2009a). Lars, who works as social worker, for instance, underlines that 'parents come from countries where the school system is completely different', implying that they have completely different view of upbringing and expectations of schools:

\footnotetext{
'Teachers cannot handle this. They set no boundaries, they are wimpy'. Parents are more familiar with an authoritarian school-system, where school steers, so then they say: 'In school, the kids are those who decide'.
}

Comparably, police officer Andreas speaks of 'migrant parents' who have a 'completely different mind-set about sentence than they have in so-called West', and they think that society 'indulges' and 'pets with people'. According to police officer Ingvar, there are significant differences between Swedish authority and these parents' views on both society and upbringing: 'if you are talking to a father here, he could hit a child', which according to him would not be possible in other parts of the city. This is indeed one of many examples of problematisations based on culturalisation, that is to say an essentialist approach based on a 
dichotomy between Us and Them, where presumed cultural differences are used as a means of explaining differences in individual behaviours, and where 'migrants' are most often seen as homogenous carriers of inherited cultures and traditions, rather than as individuals (Kamali, 2006; Dahlstedt and Lozic, 2017).

In the interviews, parents' authoritarian approach is frequently associated with gender and different ways of bringing up girls and boys (cf. Eriksson, 2003; Mattsson, 2005; Eliassi, 2014). When for instance the police officer Andreas discusses his work with disorderly youth, he points out that girls seldom pose any real problems, as they are 'usually controlled hard'. Boys, however, 'are let loose'. In other words, migrant families make a sharp distinction between how girls and boys are supposed do be brought up. The same argument is also made by Daniella, who works for an NGO aiming at strengthening young women and girls in the area. She argues that parents in the Neighbourhood 'do not think that girls should engage in recreational activities', and instead insist that girls should engage in tasks that belong to the private sphere. Nevertheless, it is not only parents who exercise control over family, here children in general and sons in particular play an important part. According to Daniella, brothers play an exceptionally important role in maintaining the authoritarian upbringing and patriarchal relationships that exist in some 'migrant families':

\footnotetext{
Girls should take care of their older brothers. [...] They cannot even imagine that their older brother could take care of her, cook and wash or similar. She must do this on his older brother's behalf. However, if older brother comes here and says, 'Now you have to home!' then she must go home. There is no way of saying 'no!' So the control doesn't only come from parents.
}

All things considered, there is a quite contradictory problematization of the migrant background of the parents appearing in the interviews. On the one hand, parents are described as unable to draw boundaries as well as excessively indulgent and irresponsible, and on the other hand they are represented as overly controlling, advocating authoritarian upbringing, which is not consistent with the norms prevailing in Sweden. In this regard, the differentiation between upbringing of males and females is referred to as a clear example of the disproportionate control said to characterize upbringing in 'migrant families'. In both cases, however, the 'migrant family' is represented as deviant and problematic - and thus made into the target of interventions of certain kinds.

\section{Fostering parents as solution}

Turning to the main solutions addressed by the interviewees, there is one dominant theme appearing, and that is how to deal with the families in the Neighbourhood, their structures and relations, and particularly how to deal with the parents in the Neighbourhood. A dominant conception amongst the interviewees is that parents need to take more responsibility for not only their own personal development, but also the future of their children and the

Neighbourhood. Thus, following such a rationality, the parents need to be transformed - or fostered - in order to become more active and responsible and on a pair with residents living in other (i.e. 'normal') parts of the city.

For instance, according to Karl, working as a coordinator for an agency with the main focus of improving the lives of children, one crucial solution is the 'strengthening of parents', so that they not only 'learn basic things about our society' but above all participate in processes of transformation of their children's lives and the life of the Neighbourhood at large. Along similar lines, Nicklas, working as an area developer, argues that 'you need to work with parents, teach them how to deal with kids'. In other words, working with parents involves not 
only providing them with useful information on how society functions and how desirable citizen-subjects ought to behave, but also shaping their thoughts, values and norms (Mulinari 2015). Consequently, if parents were to successfully raise their children, then, the argument goes, parents need to be taught the dominant norms of parenting and citizenship.

One such norm is achieving involvement. According to Raul, who is responsible for managing, developing and coordinating recreational activities and facilities in the Neighbourhood, and Thalia, a manager of an NGO working with youth, achieving involvement is about building vigilance of parents in their children's in and out of school activities. Similarly, Gabriella, who works as a drama teacher, actor and culture professional, argues that it is challenging to develop parents' involvement in children but also to 'get parents to feel engaged as well as obtain their engagement' in the culture activities that she is coordinating. The police officer Ingvar further stresses the need of informing parents about 'what child upbringing is about', because 'if you are here in Sweden then you raise children in one way, and if you are in African countries then you raise them in a different way'. Hence, in line with such reasoning, the fostering of involved parent implies assimilation to a particular normality, defined in terms of 'Swedish-ness'.

For such fostering to come to existence, there is a need for acts of and platforms for communication with the residents (Dahlstedt and Hertzberg, 2011; Magnusson, 2014). An important factor in this context is building trust, which entails establishing trustworthy relationships with and affective attachment to parents. In line with such a rationale, Karl emphasizes the importance of understanding the needs and experiences of the residents as a means for getting them involved:

People need to feel that they belong somewhere, that they contribute, that they have a meaning and they do not feel that in the system available today. [...] You are nowhere viewed as an individual; no one sees your ambitions and potentials.

The platforms for the building of relationships and communication between organisations and the residents of the Neighbourhood include - among other things - workshops and parenting classes, cultural events and festivals, surveys, door-to-door campaigns and civic centres. The prevailing idea behind such initiatives is the importance of establishing cross-organisational partnerships making it possible to reach out to the residents, and as a means of developing contacts between organizations and residents; catalysing new ideas; vanquishing the trap of rigidity that is regarded as an effect of organisational fragmentation; joining organisational forces in combating social problems and thus enabling a more effective exercise of authority; and obtaining local resilience, support and reliance (Lozic, 2016).

One of these initiatives is Home-get-togethers (HGT:s), focused on the creation of contentment, and caring and trustworthy relationships between the police, emergency service and municipality representatives on the one hand and women in the Neighbourhood on the other hand (field notes). In the first place, the concept of HGT:s is based on self-sustainment, meaning that each get-together should be organised by a local host who would invite other women from its social networks to their own homes, where they would meet representatives of the organisations. Instead of the residents visiting the organisations during office hours, as is customary, HGT:s bring the organisational representatives to the homes of local women after office hours. Indeed, the central catalyst for the success is considered to be residents' 'ownership' of the initiative (field notes). 
The premise is that the achievement of emotional attachment and ownership facilitates a more effective and efficient realisation of the goals of the HGT:s (i.e. the prevention of juvenile crime through the fostering of residents in general and mothers in particular). As one of the involved mothers puts is, in a local information leaflet about the HGT:s distributed among the residents in the Neighbourhood:
Everybody agrees that as a parent, one has an enormous responsibility - always to talk to and be involved in children's lives. As a mother, I reflect all the time over the importance of being a good role model - to get up and work every morning, to be a part of society and stand on my own two feet.

As presented in the leaflet, the development of engagement among the women and interaction between the organisations and the women, is a crucial means of developing residents able to and having an ambition to 'influence what is happening outside their front door, in the block or at the grocery store'.

Furthermore, from the perspective of organisations, the success factor is the contingency to meet residents in a relaxed and familiar environment of their own homes and discuss safety and security issues in the evenings (interview with Stefan, the representatives of emergency service; field notes from partnership meetings). Among the inducements we find 'candy, fruit and cakes' and 'smell of freshly brewed coffee that help guests to perk up' (local information leaflet). Rather than appearing in official uniform, the representatives for the organisations come in plain clothes. Not surprisingly, the municipality communication office argues that:

\footnotetext{
The appointed hour for the get-together has quickly turned to two hours. Amidst the earnestness there is laughter. Relationships have been established and meetings created. No one wants to go home. A woman offers to be the hostess for the next home get-together. Next get-together is quickly booked. Outside it is still raining, but inside there is glow that will heat for a long time (Local information leaflet).
}

Evidently, the overarching premise is that small size of HGTs and 'easy-going' and 'intimate atmosphere and talks' contribute to 'relationship building', 'engagement of residents', the enhancement of 'democratic influence of the citizens', and in the long run 'generate secure Neighbourhood' (ibid.). The relationships are here personal and affective, rather than juridical and schematised, blurring the boundaries between private and public, socialisation and persuasion, professional relationships and friendship, distance and proximity, empowerment and normalisation (cf. Lozic, 2016).

Hence, the HGT:s is an illustrative example of a range of initiatives targeting the Neighbourhood, providing representatives of various organisations with an opportunity to reach and communicate with a category of people (in this case Arabic speaking women) which is otherwise seen as particularly difficult to reach through usual communication channels. Additionally, through such learning occasions, the female residents can be 'strengthened' in their role as citizens, as they are given an opportunity to articulate their own opinions, expectations and experiences, while setting the agenda for the meetings. At the same time, the meetings can bring about a kind of active, committed and responsible subject, engaged in its own development as well as the development of the local community. Furthermore, the organisational representatives can gain insight into and greater knowledge about the lives of female participants.

Such interventions have the following rationality: The Neighbourhood and the parents living there have been identified as problems, and thus made targets for intervention - i.e. various 
means of developing the parents into active, engaged and responsible individuals. Here, the focus of the problems identified as well as the solutions made possible by these ways of representing the problem is put on the area as such - the Neighbourhood - and its inhabitants. Among the interviewees, there is hardly no critical reflection made on this particular focus on the individual, in the way in which the problem of juvenile delinquency is dealt with. However, one such reflection is made by social worker Fredrik, in contrasting the focus on the individual of today, with the focus on the structural and societal in the 1970s.

\footnotetext{
If a youth had made a break-in at a grocery store in the quarter, as in the old days, we always wrote one or two structural explanations: 'John Doe has difficulties in his leisure time, due to deficiencies or lack of leisure centres in the area'. And so on. Then there was a focus on the lack of society, while today there is a focus not on the lack of society or on John Doe's upbringing, but on himself as the one responsible for his own situation.
}

Except for this historical account about different ways of approaching social problems in general and juvenile delinquency in particular, there seems to be a consensus among the interviewees, that a focus on the the Neighbourhood and the parents is the proper means of responding to the problem of juvenile delinquency - or possibly the only means of responding to this problem that is possible to imagine.

\section{Discussion}

The aim of this article has been to analyse organizational representatives' articulation of causes of and solutions to the problem of juvenile delinquency in one so-called particularly vulnerable or excluded urban area, the Neighbourhood. In the analysis of interviews with the representatives of the police, social service, schools, municipality and NGOs as well as the field observations there are some variations. However, we have found two dominant articulations of causes of juvenile delinquency in the Neighbourhood, namely the urban area and the migrant background of the parents. Although there is not a one-dimensional focus on the migrant background as a problem, there is a dominant representation of the parents living in the Neighbourhood as a problem, due to a lack of will and ability among the parents to be engaged and to take responsibility. In both explanations, a distinctive boundary between the normal and the deviant is made. Whereas the deviant is located in the locality, i.e. social and physical environment of the Neighbourhood, and its predominantly migrant population, the normal is associated with the well-functioning parts of the city and Swedish-ness. Such problematisations also bring about certain solutions, which in our empirical material are centred on problematized parents, that become the main target of interventions with the aim of transforming their subjectivity and making them governable.

Generally speaking, the parents are represented as in the need of fostering in their role as parents and citizens, so that they can become more actively involved in and responsible for not only their children but also the Neighbourhood. Such fostering interventions aim at crating positive role models, parents need to be in order to raise their children into good citizens. The dominant discursive framing is then that parents need to not only be informed about how to think and behave as a good parent and citizens but they also need to develop a will to participate - and a will to change (cf. Vincent, 2000). However, in order for such fostering to happen, specific channels of and platforms for communication are needed. In the Neighbourhood, there is also a wide range of such channels and platforms making communication and the building of relationships between representatives of various organisations and different sections of the residents in the Neighbourhood possible - such as workshops and parenting classes, cultural events and festivals, surveys, door-to-door campaigns and civic centres. In line with a broader trend in the governing of welfare in 
Sweden and elsewhere (Dahlstedt, 2009b; Bengtsson and Hertting, 2015), several of these initiatives are based on collaboration between different 'partners'. These sites and means of communication, in turn, make the residents reachable and the target of change.

The main results of our analysis tie in with the results of several previous studies on the representation of multi-ethnic suburbs as well as migrants in Sweden (Ristilammi, 1993; Brune, 2004; Sernhede, 2002). The representation of parents with migrant background as causing a range of problems is by no means something new. There is a long history of policy interventions targeting families defined as Others, in the name of social cohesion, inclusion and normalisation (Donzelot, 1979; Swärd, 1993, Kamali, 2002, Jönsson, 2013). When it comes to migrant parents, they have been problematized previously, and targeted by a range of fostering interventions. Such problematizations are rather quite well documented in previous research - both in Sweden (Ålund, 1991; Mulinari, D, 2015) and in other countries (Lawrence, 1982; Franklin and James, 2015; Grillo, 2008). In line with some of these studies, one could describe the way of representing parents of the Neighbourhood in terms of culturalisation - i.e. as means of portraying parents as different on the basis of their ascribed ethno-cultural origins or migrant background (Ålund, 1991; Kamali, 2009).

By problematizing both the Neighbourhood and the parents of migrant background living there, as well as representing the Neighbourhood and the parents as deviant Others, the problem of juvenile delinquency is more or less decoupled from wider structural settings. Thus, issues of inequality and discrimination are silenced and un-problematized (cf. Ålund, 2002; de los Reyes and Kamali, 2005). According to such rationality, the solution to the problems identified are located within the Neighbourhood and among those categorised as themselves constituting the problem (cf. Ekholm, 2016). Here, the line of argument is that those who are excluded can become included, if they are activated, able and willing to take responsibility. Referring to Cruikshank (1999), such interventions of activation could be seen as a quite paradoxical form of governing - a will to empower: on the one hand empowering, in the sense of striving to motivate and release the inner creativity of the individual, on the other hand disciplinary, in the sense of emphasising active participation and adaptation to norms of Swedish-ness as an obligation (cf. Hörnqvist, 2010; Wright Nielsen, 2015; Ekholm and Dahlstedt, 2017). In line with such a rationality, those who choose not to become activated, those not making the right choices, and those who are not capable of realising and taking the long-term consequences of their choices into consideration, only have themselves to blame (Vanderbreck, et al. 2011).

Such rationality is, in a way, symptomatic for a political situation, in Sweden, as well as in many other countries, where the focus in political discourse is put on the individual, for her responsibility for adaptation and normalisation, rather than on the structural, for initiating measures of structural change (cf. Davidson, 2010; Larsson, et al. 2012). This raises a number of questions in need of elaboration and further research: How may the relations between the empowering and disciplinary forms of governing discussed here be analysed in the context of cross-organisational partnerships, involving a wide range of partners, with different roles, responsibilities and relations to each other? What kind of interventions are made possible in such partnerships, where boundaries between different partners are crossed, in the search for developing joint, sustainable means of responding to the challenges of juvenile delinquency? In relation to such questions, comparative studies would be of particular importance, in providing insight into similarities as well as divergencies between interventions made in various localities, addressing further issues of local interpretations and manoeuvre by professionals working in the 'front-line'. 


\section{Acknowledgements}

This work was supported by the Swedish Research Council (Grant number 721-2013-885).

\section{References}

Abiala, K, 2014, Brinner 'förorten'?, Södertörn University.

Ålund, A, 1991, Lilla Juga, Stockholm: Carlssons.

Ålund, A, 2002, Sociala problem i kulturell förklädnad, in: A, Meeuwisse and H, Swärd (eds)

Perspektiv på sociala problem, Stockholm: Natur och kultur.

Bacchi, C.L, 1999, Women, policy and politics, London: Sage.

Bacchi, C.L, 2010, Foucault, policy and rule, Aalborg: Aalborg University.

Bacchi, C.L, 2012 Why study problematizations?, Open Journal of Political Science 2,1, 1-8. Bengtsson, B, and Hertting, N, 2015, Makten i den etnifierade staden, in: B, Bengtsson et al. (eds) Mångfaldens dilemman, Malmö: Gleerups.

Boréus, K, 1994, Högervåg, Stockholm: Tiden.

Brune, Y, 2004, Nyheter från gränsen, Gothenburg: Gothenburg University.

Chandler, D, 2014, Resilience. Abingdon: Routledge.

Cruikshank, B, 1999, The will to empower, Ithaca: Cornell University Press.

Dahlstedt, M, 2009a, Parental governmentality, British Journal of Sociology of Education 30, 2, 193-205.

Dahlstedt, M, 2009b, Aktiveringens politik, Malmö: Liber.

Dahlstedt, M, 2015, Discourses of employment and inclusion in Sweden, in E. Righard, et al. (eds) Transformation of Scandinavian cities, Lund: Nordic Academic Press.

Dahlstedt, M and Hertzberg, F, 2011, Skola i samverkan, Malmö: Gleerups.

Dahlstedt, M and Lozic, V, 2017, Färgblind fostran, in T. Hübinette (ed) Ras och vithet,

Lund: Studentlitteratur.

Davidson, T, 2010, Utanförskapelsen, Socialvetenskaplig Tidskrift 17, 149-169.

Dean, M, 1999, Governmentality, London: Sage.

de los Reyes, P, et al. 2014, 'Bilen brinner, men problemen finns kvar...', Stockholm:

Stockholm University.

Donzelot, J, 1979, The policing of families, London: The John Hopkins University Press.

Ekholm, D, 2016, Sport as a means of responding to social problems, Department of Social and Welfare Studies, Linköping University.

Ekholm, D and Dahlstedt, M, 2017, Technologies of solidarity, Social Inclusion

(forthcoming).

Eliassi, B, 2014, Constructing cultural otherness in the Swedish welfare state, Qualitative Social Work 14, 554-571.

Ekberg Stigsdotter, M, 2010, Dom kallar oss värstingar, Växjö: Linnaeus University Press.

Eriksson, M, 2003, I skuggan av pappa, Stehag: Gondolin.

Foucault, M, 1991. On governmentality, in G. Burchell et al. (eds) The Foucault effect, Brighton: Harvester.

Foucault, M, 2004, Polemics, politics, and problematizations, in: P. Rabinow (ed.) The Foucault reader. London: Penguin Books.

Franklin, D and James, A.D, 2015, Ensuring inequality, Oxford: Oxford University Press.

Grillo, R.D, (ed) 2008, The family in question, Amsterdam: Amsterdam University Press.

Gruber, S, 2007, Skolan gör skillnad, Department of Social and Welfare Studies, Linköping University.

Hallin, P.O, et al. 2010, Det är inte stenarna som gör ont, Urban Studies, Malmö University. Hertting, N, 2003, Samverkan på spel, Stockholm: Egalité.

Hörnqvist, M, 2010, Risk, power and the state, London: Routledge. 
Junestav, M, 2004, Arbetslinjer i svensk socialpolitisk debatt och lagstiftning 1930-2001, Uppsala: Uppsala University.

Jönsson J.H, 2015, The contested field of a caring state in a retreated welfare state, Critical and Radical Social Work, 3, 3, 347-374.

Jönsson J.H, 2013, Social work beyond cultural otherisation, Nordic Social Work Research 3, 2, 159-167

Kamali, M, 2014, Integration beyond multiculturalism, in P. v. Aerschot et al. The integration and protection of immigrants, London: Routledge.

Kamali, M, 2002, Kulturkompetens i socialt arbete, Stockholm: Carlsson.

Kamali, M, 2006, Den segregerande integrationen, Stockholm: Fritzes.

Kamali M, 2009, Racial discrimination, London: Routledge.

Kings, L, 2011, Till det lokalas försvar, Lund: Arkiv.

Korpi, W, et al, 2003, New politics and glass politics in the context of austerity

and globalization, American Political Science Review 97, 3, 425-446.

Larsson, B, et al. (eds) 2012, Transformations of the Swedish welfare state, Basingstoke:

Palgrave Macmillan.

Larsson, J.K, 2015, Integrationen och arbetets marknad, Stockholm: Atlas.

Lawrence, E, 1982, Just plain common sense, in CCSC (ed) The empire strikes back, London:

Routledge.

Leira, A, 1994, Concepts of caring, Social Service Review 68, 2, 185-201.

Lozic, V, 2016, Normalisering av ungdomar i problem genom styrning av föräldrar,

Sociologisk Forskning 52, 2, 151-174.

Magnusson, S, 2014, Att säkerställa att vi är välkomna, Lund: Lund University.

Mattsson, T, 2005, I viljan att göra det normala, Malmö: Egalité.

Mayer, M et al. 2016, Urban uprisings, London: Palgrave Macmillan.

Miller, P, and Rose, N, 2008, Governing the present, Cambridge: Polity.

Molina, I, 1997, Stadens rasifiering, Department of Cultural Geography, Uppsala University. Mulinari, D, 2015, 'Kalla mig vad fan du vill, men inte invandrarförälder', in: M, Dahlstedt, et al. (eds) Utbildning, arbete, medborgarskap, Umeå: Boréa.

Mulinari, L.S, 2015, 'Ni är inte välkomna i vårt fina Malmö’, Sociologisk forskning, 52, 4, 321-340.

Nordström-Skans, O et al., 2010, Segregationen i storstäderna, Uppsala: IFAU.

Pearson, G, 1983, Hooligan, London: Macmillan.

Ristilammi, P-M, 1993, Rosengård och den svarta poesin, Stehag: Symposion.

Rose, N, 1999, Powers of freedom, Cambridge: Cambridge University Press.

Rothstein, B, 1998, Just institutions matter, Cambridge: Cambridge University Press.

Ryner, M.J, 2002, Capitalist restructuring, globalisation, and the third way, London:

Routledge.

Schierup, C-U, et al. 2014, Reading the Stockholm riots, Race \& Class 55, 3, 1-21.

Schierup, C-U, et al. 2015, Social exclusion, in M. Dahlstedt and A. Neergaard (eds)

International Migration and Ethnic Relations, London: Routledge.

Sernhede, O, 2002, Alienation is my nation, Stockholm: Ordfront.

Sernhede, O, 2011, Inledning, in O. Sernhede (ed) Förorten, skolan och ungdomskulturen,

Göteborg: Daidalos.

Stigendal, M, 1999, Sociala värden i olika sociala världar, Lund: Studentlitteratur.

Svensson, K, 2010, Performing caring power in a Scandinavian welfare state, Social Work

Review 9, 3, 49-58.

Swärd, H, 1993, Mångenstädes svårt vanartad, Floda: Zenon.

Vanderbreck, M, Roose, R, and De Bie, M, 2011, Governing families in the social investment state, International Critical Childhood Studies 4, 1, 69-85. 
Vincent, C, 2000, Including parents?, Buckingham: Open University Press.

Wright Nielsen, T, 2015, Empowerment och normalisering, in: N, Montesino and E. Righard (eds) Socialt arbete och migration, Malmö: Gleerups. 